The Geneva Papers on Risk and Insurance, 18 (No. 68, July 1993), 292-301

\title{
20th Annual Report on the Activities of the Geneva Association
}

for the period from June 1, 1992 to May 31, 1993

\section{Studies and research projects}

1.1. Comparative study of personal injury compensation: sources and procedures in six european countries

A first intermediary report of this study was already published in "The Geneva Papers" (Nr. 56, 1990) under the title of "Comparative Liability Studies".

The second part of this study, to which experts from major insurance companies in Europe have contributed under the leadership of Dr. Werner Pfennigstorf, has now been finished. A summary has been published in "The Geneva Papers" Nr. 65, October 1992. The whole report has been published in 1993 by Lloyd's of London Press under the title "Personal Injury Compensation" (ISBN 185044 485 4, 213. p.).

This research is complementary to a similar one done by Dr. Pfennigstorf in the United States.

1.2. The research programme on "The Four Pillars" (social security, life insurance, savings and the consequences of aging)

The research activities on this issue for the last months are described in the "Four Pillars Bulletin“" Nr. 13 of November, 1992, and Nr. 14 of May, 1993.

The Geneva Association has been contributing to seminars and research programmes in this area carried forward by the "Carnegie Inquiry into the Third Age" and with written contributions to seminars in Paris, New York City and Amsterdam.

A specific study on employment after sixty years of age in Germany and its relevance for insurance has started in March 1993. The project head is Prof. Winfried Schmähl who has already contributed to our programme.

The Geneva Association has also organized a seminar on the issue of the four pillars in New York on March 26 at the occasion of the Fifth Annual International Conference of the Society for the Advancement of Social Economics (SASE) at the Graduate Faculty of the New School for Social Research in New York City. Have contributed to this session Prof. Yung-Ping Chen of the Department of Gerontology at the University of Massachusetts, Prof. Chris Trinder of the Public Finance Foundation in London, Dr. Lei Delsen of the Nijmeigen University (Netherlands), Prof. Noriyuki Takayama from Hitotsubashi University in Tokyo, Prof. Peter Doeringer from Boston University and Mrs. Geneviève RedayMulvey of the Geneva Association. 


\subsection{Studies on risk management and industrial risks}

In July, we have published in "The Geneva Papers" Nr. 64 a special issue in this area with the collaboration of Felix Kloman of Tillinghast on "Risk Management Today" (nine contributions to evaluate the development of risk management in the world); this issue contains also a dossier on "Climatic Change and Insurance" and a summary of the study on "Risk Management in the Catering Industry".

The Risk Management Newsletter Nr. 13 has been published in September 1992 and Nr. 14 has been published in April 1993. This Newsletter contributes to the exchange of information in this area worldwide (it is diffused to 2100 addresses).

We have also published in the "Etudes \& Dossiers" series (Nr. 170, August 1992) a dossier with the papers presented at the MORE (Management of Risk in Engineering) Seminar Nr. 8 on "The Risk Management of Computers and Electronic Equipments".

Within the framework of the programme concerning risk and economics teaching for engineers, we have published in the "Etudes \& Dossiers" Nr. 176 a study done under the auspices of the Geneva Association by the CINEAS (Polytechnic of Milan) on the courses provided on risk economics and engineering in Italy. This publication follows those which have been produced in the past by the Geneva Association for the Scandinavian countries, Holland, the UK and Germany.

\subsection{Research work on private insurance in the European Communities and the agreement between the Communities and Switzerland}

This study was first published in French in the "Etudes \& Dossiers" series Nr. 149 to 152. The English and German updated versions of this study are now under consideration. A special seminar on this issue has been held in Zurich on December 10 and 11 at the main office of the Zurich Insurance Company.

\subsection{Study seminars on the Accounting Directive of the European Communities}

With the contribution of Dr. Hans-Joachim Welzel, Vice Secretary General of the Geneva Association and of experts of KPMG from Germany, the United Kingdom and other countries, five seminars have been organized:

- A first one in Milan on October 13 with the collaboration of CESAR (Italian Center for Insurance Research).

- On November 19 in Lisbon in collaboration with the Portuguese Federation of Insurance Companies.

- A third presentation on this issue has been organized in Athens in collaboration with the Greek Federation of Insurance Companies on April 5, 1993.

- A fourth seminar has been organized in Budapest on May 20 and 21, 1993.

- A fifth session has been organized in Vienna on June 8, 1993, in collaboration with the Austrian Federation of Insurance Companies.

\section{Conferences and seminars}

\subsection{Geneva Lectures}

- The 9th Geneva Lecture bas been organized in London on September 23rd, 1992 with the contribution of Dr. J.F. M. Peters, Chairman of the Executive Board, AEGON N.V., 
Netherlands, Mr. Björn Wolrath, President and Chief Executive Officer, SKANDIA GROUP, Sweden, and Mr. W. Nelson Robertson, Chief General Manager, GENERAL ACCIDENT GROUP, Scotland.

The theme of this lecture was "Patterns of Internationalization for Insurance". The text has been published in "The Geneva Papers" Nr. 67, April 1993.

- The 10th Geneva Lecture has been organized in Vienna, on October 16, with the collaboration of the Munich Re. Mr. Peter Sellschopp, Member of the Board of the Munich Re, presented a paper on "Aktuelle Fragen der Umwelthaftung und ihre Versicherung". An English version of the lecture has been published in the "The Geneva Papers" Nr. 67, April 1993.

- The 11th Geneva Lecture has been organized in Lisbon on May 25 with the collaboration of the Munich Re. Mr. Göbel, Member of the Board of the Munich Re, presented a paper on "World Insurance - Possibilities, Risks and Perspectives".

\subsection{9th Seminar of the European Group of Risk and Insurance Economists}

This seminar has taken place at the City University in London on September 21st to 23rd, 1992. Details are given in the "Newsletter" of January 1993. At this occasion, the 4th Geneva Risk Economics Lecture was given by Prof. Michael Brennan, University of California at Los Angeles on "Aspects of Insurance and Intermediation".

The 20th Anniversary of this series of seminars has been organized at the University of Rotterdam on September 20-22, 1993 with the managerial contribution of Prof. Lutgart Van den Berghe and Prof. G.W. de Wit.

\subsection{Seminars and meetings on the service economy}

- 8th Seminar of PROGRES (Programme of Research on the Economics of Services) was organized in Geneva on September 28, 1992. This meeting has gathered about 30 service economists from Eastern and Western Europe. It is within the framework of this seminar that insurance is proposed as a key activity in the service economy.

- The third meeting of ASEC (Applied Service Economics Center) has taken place in Geneva on September 29, 1992, with the contribution of experts and negotiators of the Uruguay Round at GATT. The Geneva Association has contributed to the organization of this meeting together with several other organizations involved and interested in services negotiations.

\subsection{The fifth joint conference between the European Association of Law and Economics and the Geneva Association}

The fifth Joint Conference Between the European Association of Law and Economics and the Geneva Association for the study or risk and insurance has taken place in Geneva on April 5 and 6, 1993, on The Law and Economics of Insurance and of Services. 32 participants from 18 universities in Europe and the United States have contributed. Papers.

The best papers produced at this occasion are due for publication in The Geneva 


\subsection{Fifth seminar of the World Fire Statistics Center}

We have organized in Geneva on May 5 and 6 the fifth Seminar of the World Fire Statistics Center, in conjunction with the European Arson Prevention Institute. This seminar has gathered about 40 experts on fire statistics and arson related to fire from most European countries and the United States.

Mr. Tom Wilmot, who made the first study on fire statistics for the Geneva Association as early as 1975 , is still collaborating with the United Nations in Geneva for the preparation, diffusion of questionnaires and collection of datas worldwide.

\section{Others}

\subsection{Project for an international programme on higher education in insurance}

A meeting on this issue which has been promoted two years ago by the Chartered Insurance Institute and CAPA has been held in Geneva on June 22nd. Professor Lutgart Van den Berghe has pursued a series of contacts to evaluate the possibilities of such a programme. The results of this enquiry are presented at the General Assembly of the Geneva Association with the contribution of Prof. Dr. Dieter Farny.

\subsection{Bi-annual meetings in Venice of the Insurance Research Centers}

The second bi-annual meeting of the Insurance Research Centers will take place in Venice on October 14 and 15, 1993, with the collaboration of CESAR (Center for Insurance Research, Italy). The most important insurance research Centers in Europe are represented, as well as from the United States and Canada.

\subsection{The international insurance seminars founders' award of excellence 1993}

Over thirty personalities and experts in various sectors of the insurance industry from all over the world have met last March in the United States to decide about the 1993 I.I.S. Founders Award of Excellence.

The Price for this year has been awarded to Dr. Orio Giarini, Secretary General of the Geneva Association, who has been in charge of the development of this "think-tank" of the world insurance industry since its beginning, twenty years ago.

A special official ceremony was organized for the presentation at this award on the occasion of the first opening day of the International Insurance Seminar in Tokyo on July 12,1993 . This event is largely supported by the Japanese insurance companies.

\subsection{World insurance day}

Dr. Ladislaus Viragh, former Member of the Board of Erste Allgemeine in Austria has proposed to celebrate a World Insurance Day, during which insurance companies, insurance institutions and organizations would present their activities and discuss key issues of insurance during the same day worldwide. This idea is meant to contribute to the promotion of the image of insurance simply by coordinating existing activities. A committee has been founded in Vienna, and has had its last meetings on July 15 and 16, 1992 and on January 13, 1993 in Brussels. This initiative might combine with a similar one already going on in Latin America and Spain, normally taking place in May. The project is under scrutiny. 


\subsection{Publications}

\subsubsection{The Geneva Papers on Risk and Insurance - Issues and Practice}

- Nr. 64, July 1992: Risk Management Studies; Studies on Climatic Change; Managing Risk in the Catering Industry

- Nr. 65, October 1992: Law and Economics of Environmental Policy

- Nr. 66, January 1993: The Economics of Insurance (now being translated into Spanish by FIDES for Latin America)

- Nr. 67, April 1993: 8th, 9th and 10th Geneva Lectures of the Geneva Association, and Insurance Issues.

\subsubsection{The Geneva Papers on Risk and Insurance - Theory}

- Volume 17, Nr. 1, June 1992

- Volume 17, Nr. 2, December 1992

- Volume 18, Nr. 1, June 1993

\subsubsection{In the "Etudes \& Dossiers" series}

- Nr. 166 - April 1992 to Nr. 169 - July 1992:

Strategic Issues and Planning in Insurance (Vol. 1 to 4). Papers from the 4th International Conference of the Geneva Association, London, October 28-30, 1991

- Nr. 170 - August 1992:

The Risk Management of and Involving Computers and Electronic Equipment. Papers from the 8th Seminar of M.O.R.E. organized by the Geneva Association and the Liverpool Polytechnic. Liverpool, March 3 and 4, 1992.

- Nr.171 - September 1992:

Studies on Productivity in Insurance and Services.

- Nr.172 - October 1992:

Papers from the 19th General Assembly of the Geneva Association. Madrid, May 11-12, 1992.

- Nr.173 - November 1992:

Papers from the 19th Seminar of the European Group of Risk and Insurance Economists. London, September 21-23, 1992.

- Nr. 174 - January 1993:

Papers from the Insurance Workshop organized by the European Communities Commission on Moscow on March 17-20, 1992.

- Nr. 175 - February 1992:

Analysis of the Accounts Directive in the European Communities

- Nr. 176 - April 1993:

"Gli insegnamenti relativi alla gestione del rischio nelle facoltà di ingegneria". This study is a complement of those already done for the Scandinavian countries, UK, and Holland, published in the "Etudes \& Dossiers" Nr. 79 and 80 (1984), and Germany, "Etudes \& Dossiers" Nr. 128 (1988).

- Nr.177 - May 1993:

Database of European University Courses in Insurance and Risk Management, The City University, London. 


\subsubsection{Lettre d'Information}

- Nr. 127 - May 1992

- Nr. 128 - May 1992

- Nr. 129 - January 1993

- Nr. 130 - May 1993

3.3.5. The Four Pillars Bulletin

- Nr. 13 - November 1992

- Nr. 14 - May 1993

\subsubsection{Risk Management Bulletin}

- Nr. 13 - September 1992

- Nr. 14 - April 1993

\subsubsection{World Fire Statistics Center Bulletin}

- Nr. 9 - July 1992

- Nr. 10 - June 1993

\subsubsection{PROGRES Newsletter}

- Nr. 16 - June 1992

- Nr. 17 - December 1992

- Nr. 18 - May 1993

3.3.9. Newsletter of the European Group of Risk and Insurance Economists

- Nr. 29 - August 1992

- Nr. 30 - January 1993

\subsubsection{Books}

- Personal Injury Compensation, edited by W. Pfennigstorf, Lloyds of London Press Ltd, London, 1993, 223. p.

- The Limits to Certainty, second revised edition, Kluwer Academic Publishers, Hingham, MA, May 1993.

\section{Lectures and interventions in international conferences}

It should be noted that in the majority of cases the lectures are given upon invitation at the cost of the organization requesting them.

- by the Secretary General

- June 19, Stresa, Lecture on "The Importance of Insurance in the New Service Economy" for the National Assembly of Italian Brokers and Agents Association.

- June 24, University of Milan, Faculty of Economics, "The Modern Economy as a Service Economy and the Function of Insurance".

- September 16 to 18 , Hannover, conference organized by the International Partnership Initiative (I.P.I.) which is a foundation supported by Volkswagen and major German companies such as Bosch and Deutsche Bank. The Club of Rome (of which Mr. Goeudevert, Managing Director of Volkswagen is member) has co-sponsored this 
initiative. Mr. Gorbatchov was one of the main speakers. We have introduced in the discussions the idea that the modern economy is a services-based economy.

- October 5, London. Keynote speech for a world congress on health and safety (organized by major international organizations with the contribution of safety and engineering experts of the most important industrial companies worldwide with 300 participants). The theme presented was "Risk Management in a Modern Service Economy".

- October 13, University of Geneva, Conference of the "Académie de l'Environnement". Presented a lecture on "Risk Management in the Service Economy".

- October 20, Geneva, Symposium organized by the "Rentes Genevoises" with the contribution of various insurance experts from Switzerland and Europe. Presented a lecture on "The Strategy of the Four Pillars in a Service Economy".

- November 2, Malta. Presentation of the research activities of the Geneva Association to the Insurance Association of Malta.

- November 3 and 4, University of Malta, Congress of the International Ocean Institute. Lecture on "Risk Management in the Modern Economy".

- November 6, University of Neuchâtel, Center for Services Studies, conference on "The Management of Risk in the Service Economy".

- November 15 to December 3: Series of lectures and presentations in Kuala Lumpur, Singapore, Xiamen (Amoy)-China, and Tokyo on the service economy and on the management of risk. Such lectures have been presented to:

The General Assembly of the Club of Rome organized by the Economic Advisory Center to the Government in Kuala Lumpur;

The Insurance Institute of Kuala Lumpur

The Insurance Institute of Singapore

The University of Singapore

The University of Xiamen, China

The International Seminar on Management of Ocean and Sea Resources The Life Institute of Japan.

- January 8, University of Geneva, international conference of "Environmental Risks", lecture on "The Growing Role of Risk Management and Insurance in the Modern Economy".

- February 11, round table of the European Institutional Investors Institute, Geneva, lecture on "Europe in the Third Age: The Effects of Demography".

- February 17, Cologne, Sport University, invitation by the rector of the university for a group of economic and political personalities of the city of Cologne ("The Club of Cologne") on "Future Perspectives of Economic Development and Risk Management".

- February 23, University of Geneva, Faculty of Social and Economic Sciences, lecture on "The Transition from an Industrial Economy to a Service Economy".

- March 19, New York, 20th Anniversary of the "Risk Management Report" by Tillinghast. Introductory lecture on "The Role of Risk and Insurance in the New Service Economy".

- March 28, New York, international conference of the Society for the Advancement of Socio-Economics, New School of Social Research, lecture on "The Role of Services and the Management of Uncertainty in the Modern Economy: Some Key Issues in Economic Theory". 
- April 1, Geneva, Demographic Center of the University of Geneva, seminar on "Family and Social Solidarities", lecture on "Wealth Accumulation and the Four Pillars Strategy in the New Demographic Perspectives".

- May 14, Istanbul, international seminar organized by Bull. Contribution to an introductory panel on "The Perspectives of a Service Economy for a Recomposition of the Economic and Political Consensus in the Future of Europe - the Function of Risk Management and Insurance".

- by Walter R. Stahel, Deputy Secretary General

- June 9, 1992, Bern, Jahrestagung des Schweizerischen Versicherungs-Verbandes.

- June 24, 1992, University of Lowell, MA, conference by the Massachusetts Toxic Use Reduction Institute on Design for the Environment; paper on "What is Design for Environment?"

- June 25-26, 1992, Conference at Haus der Technik, Essen on Productrecycling in der Elektro- und Elektronikindustrie, Lecture on "Abfallvermeidung durch dauerhaftere Produkte".

- July 13-17, 1992, Woods Hole MA, USA, workshop by the National Academy of Engineering, paper on "Utilization focussed Service economy - resource efficiency and waste prevention".

- November 11-13, 1992, NordRM'92 in Copenhagen / Denmark, organized by UNIRISK Sweden, paper on "Risk Management and Insurance - A Conflict of Interest?".

- December 8-11, 1992, EPA Conference at Minneapolis on Household Hazardous Waste Management, paper on "Design for the Environment - Household Goods" (published in conference proceedings).

- February 2-3, 1993, OECD, Paris, invited expert to the workshop on the Final Report of the Programme on Technology and the Environment.

- March 2, 1992, University of the German Armed Forces, München, Seminar on "Resource Efficiency as a Strategy Towards a Sustainable Economy".

- March 3-5, 1993, participation at the Jahrestagung des deutschen Vereins für Versicherungswissenschaft e. V., Karlsruhe.

- March 16, 1993, Flensburg, Seminar of the Ministry of the Economy of Schleswig-Holstein, paper on "Eco-Products and Product Responsibility".

\section{- by Dr. Hans-Joachim Welzel, Vice Secretary General}

- Seminars in collaboration with KPMG: Analysis of the Insurance Accounts Directive in the European Communities:

- October 13, 1992, Milan

- November 19, 1992, Lisbon

- April 5, 1993, Athens

- May 20-21, 1993, Budapest

- June 8, 1993, Vienna. 
- Publications:

- in the Etudes \& Dossiers series No. 175, "Analysis of the Insurance Accounts Directive in the European Communities"

- in The Geneva Papers on Risk and Insurance No. 67, April 1993, on "The Supervision of Financial Conglomerates".

- by Gerry Dickinson, Vice Secretary General

- June 25, 1992, London, attended the annual meeting of LIRMA.

- July 1-3, 1992, Paris, talk on "Regulation on the investment of insurance company funds, lessons for the emerging insurance markets of central and eastern Europe", conference organized by the Insurance Committee of the OECD.

- September 21-23, 1992, London, organization (and joint chaiman) of the 19th Annual Seminar of the European Group of Risk and Insurance Economists. Paper (with E. Dinenis) on "Allowing for the liabilities of life insurance companies in mean/variance investment models".

- December 18, 1992, Warsaw, Institute of Insurance and Banking, talk on "The role of the insurance industry in economic development".

- January 14, 1993, Brussels, attended and contributed to the meeting organized by Prof. L. van den Berghe of the "European Management Center" to set up pan-European managements courses.

- April 27-29, 1993, Moscow, First International Insurance Rendez-Vous, paper on "The role private insurance can play in encouraging savings and stimulating the development of capital markets".

- by François-Xavier Albouy, Deputy Secretary General

- Preparation and enquiry for a research programme on distribution systems

- Contribution to the Insurance Workshop organized by the European Communities Commission in Moscow, on March 17-20, 1992.

- by Geneviève Reday-Mulvey, Researcher

- January 27, 1993, Amsterdam, Creation of an European Network on Work and Aging.

- January 28-30, 1993, European Symposium on Work and Aging, Amsterdam, Poster presented with a short paper on "The Fourth Pillar: a Contribution to the Work and Aging Issue".

- March 26-28, 1993, New York, Conference of the Society for the Advancement of SocioEconomics, organization of a session on Work and Aging with four speakers and two discussants.

- April 28-29, 1993, London, Carnegie European Conference on "Life, Work and Livelihood in the Third Age".

Publications and other works:

- November 1992, Publication of an article in FUTURIBLES, Paris, on "Vers un allongement de la vie professionnelle?".

- March 1993, Publication of an article in POINTS-CADRES, Paris, on "Vers la retraite à la carte?".

- 1993 Research: Continuing training and education of older workers and people. 
- February 12, 1993, Philadelphia, at the Steinberg Conference Hall, Mr. Norman A. Baglini, President and chief Executive Officer of the American Institute for Chartered Property Casualty Underwriters - Insurance Institute of America and Member of the Editorial Board of the Geneva Papers, contributed for the Geneva Association to the conference on "The Impacts of Environmental Risks on Real Estate Transactions".

- In addition, Mr. Roger Merkelbach, as a fall-out of his study with Christian Grosjean on the consolidation of European insurance law:

- May 23, 1993, Marmaris-Turkey, lecture on "Insurance: Development of Common Rules, Mutual Recognition of National Rules, Treatment of Foreign Insurance Companies" for a seminar on "Services in the European Communities" for high level officials (about 100), under the auspices of the Turkish Ministry of Finance.

\section{Personal contacts with the members}

From June 1st to May 30, 1993, 32 members of the Geneva Association have been contacted personally, in order to have their views on the future developments of the Geneva Association and the priorities to be considered for future activities. About 15 additional letter exchanges with our members have extended this inquiry.

A study under the supervision of Prof. Dr. Dieter Farny, approved at the meeting of the Board in London on January 15, 1993, will complement systematically this enquiry. 